\title{
'Bana Arkadaşını Söyle, Sana Yenilikçi Olup Olmadığını Söyleyeyim': Akran Sosyalleşmesinin Tüketici Yenilikçiliğindeki Rolü*
}

\author{
Tuğba KILIÇER** Eda PAÇ ÇELİK ***
}

\begin{abstract}
$\ddot{O} Z$
$B u$ araştırmanın amacı, akran sosyalleşmesinin genç tüketicilerin moda yenilikçilik eğilimlerinde nasıl bir rol oynadiğını incelemektir. Veriler bir devlet üniversitesindeki ögrencilerden kolayda örnekleme yoluyla anket tekniği ile toplanmıştır. Verilerin analizinde açıklayıcı faktör analizi, kümeleme analizi ve tek yönlü Varyans analizinden yararlanılmıştır. Katılımcllar akran sosyalleşmesi açısından düşük, orta ve yüksek eğilimlilerin yer aldığı üç farklı kümede toplanmıştır. Bu kümeler, arkadaş tutkunları, arada kalanlar ve bağımsızlar olarak adlandırılmıştır. Kümeler içerisinde moda yenilikçilik eğilimi en yüksek küme arkadaş tutkunları iken, moda yenilikçilik eğilimi en düşük küme bağımsızlardır. Elde edilen sonuçlar doğrultusunda uygulamacılara ve gelecekte yapılacak araştırmalara yönelik öneriler tartışılmıştır.
\end{abstract}

Anahtar Kelimeler: Akran Sosyalleşmesi, Tüketici Yenilikçiliği, Genç Tüketici

JEL Sınıflandırması: M30, M31

\section{'Tell Me Your Friend, I Tell You Whether You Are Innovative': The Role of Peer Socialization on Consumer Innovativeness}

\begin{abstract}
The aim of this study is to investigate the role of peer socialization on consumer innovativeness of young consumers. A questionnaire was applied to students attending a state university through convenience sampling. The data was analyized through factor, cluster and one way ANOVA analyzes. Participants could be grouped in three separate clusters with respect to their adoption of peer socialization. Fashion innovativeness tendency of friend devotees is highest in these distinctive profiles. On the other hand, fashion innovativeness tendency of dependents is lower than the other clusters. The researchers also discuss managerial implications and directions for future research.
\end{abstract}

Key Words: Peer Socialization, Consumer Innovativeness, Young Consumers

JEL Classification: M30, M31

\section{GíRIŞ̧}

İşletmeler günümüzün rekabetçi koşullarında sürdürülebilir bir başarı elde etmek, pazardaki mevcut konumlarını muhafaza etmek, pazardaki yeni eğilimlere hızlı bir şekilde karşılık vermek ve markalarını dinamik ve yenilikçi bir marka olarak konumlandırmak için ürün ve hizmet yeniliklerine önem vermek

\footnotetext{
* Bu çalışma, "International Congress of Politics, Economics and Social Studies (ICPESS 2017)" de sözlü olarak sunulmuş ve özet kitapçı̆̆ında basılmış çalışmanın geliştirilmiş halidir.

** Dr.Öğr.Üyesi Tokat Gaziosmanpaşa Üniversitesi İktisadi ve İdari Bilimler Fakültesi, İşletme Bölümü. tugba.kilicer@gop.edu.tr

***Arş.Gör. Tokat Gaziosmanpaşa Üniversitesi İktisadi ve İdari Bilimler Fakültesi, İşletme Bölümü eda.pac@gop.edu.tr
} 
durumundadırlar. İşletmelerin ürün ve hizmet yeniliklerinin pazar koşullarında başarılı olması ise önemli ölçüde tüketicilerin bu yenilikleri benimsemesine ve yayılmasına bağlıdır. Pazara sunulan yeni ürünlerin benimsenmesinde ve yayılmasında yenilikçi tüketiciler etkili olabilmektedir. Yenilikçi tüketiciler yeni çıkan ürün ve markaları diğer tüketicilere göre daha sık satın alan, fiyat hassasiyeti daha düşük tüketici grubunu ifade etmektedir. Yenilikçi tüketiciler ürünleri kullanarak diğer tüketicilere bilgi ve deneyimlerini aktarmakta ve onların da tüketim tercihlerini etkilemektedir. Bu yüzden işletmeler yenilikçi tüketicilere önem vermekte ve onların diğer tüketicileri etkileme gücünden yararlanmaya çalışmaktadırlar.

Genç tüketiciler yeni ürünlerin benimsenmesinde işletmelerin özel önem verdiği, enerjik, deneyime açık bir tüketici grubu olarak karşımıza çıkmaktadır. Özellikle ergenlik döneminden itibaren gençler tüketimi gündelik yaşamda bir sosyalleşme aracı olarak görmeye başlamakta, tercih ettiği markalar ve ürünlerle kimliğini ortaya koymaya çalışmaktadır. Bu dönem tüketim tercihlerinde ailenin etkisinin azalmaya başladığı, arkadaşların ve kitle iletişim araçlarının genç tüketicinin kararlarında daha belirleyici olmaya başladığı bir dönemdir. Akran grupları genç tüketicilerin gündelik yaşamlarının önemli bir parçası ve önemli bir referans grubudur. Genç bir tüketici dahil olduğu akran grubuyla birlikte vakit geçirmekte, sosyalleşmekte ve tüketim aktivitelerinde bulunmaktadır. Genç tüketicinin dahil olduğu grup ile samimiyeti arttıkça bu etkileşimlerin düzeyi de artmaktadır. Bu sosyalleşme anlarında akranların kullandığı markalar, yeni ürünlere ilgisi genç tüketicilerin dikkatini çekebilmektedir. Genç tüketiciler akranlarından etkilenerek onlar gibi giyinmeye, onların kullandıkları markaları, eşyaları kullanmaya başlayabilmektedir. Bunun yanı sıra akranların ürünlerle ilgili tavsiyeleri de sohbetlerin konusu olabilmektedir. Genç tüketiciler akran grubu içerisindeki konumunu sağlamlaştırmak, grup üyelerini etkilemek istediğinde ürün tercihlerinde akran tavsiyelerinin etkisi daha da artmaktadır (Workman ve Studak, 2006; Lanchance vd., 2003). Tüm bu etkileşimler göz önünde bulundurulduğunda akran sosyalleşmesinin tüketici yenilikçiliği ile olan ilişkisinin incelenmeye değer olduğu görülmektedir.

İlgili yazın incelendiğinde yabancı yazında genç tüketicilerde akran sosyalleşmesinin tüketici yenilikçiliği ile ilişkisinin az sayıda çalışmada ele alındığ 1 görülmektedir. Buna göre akran gruplarının normatif etkileri (Lee, 2014; Muratore, 2008; Lachance vd., 2003; Lee, 2014) ve bilgilendirici etkileri (Mangleburg ve Bristol, 1998; Xie ve Singh, 2007; Singh vd., 2003) gençlerin yenilikleri deneyimlemeleri üzerinde etkili olabilmektedir. Bu etki kimi zaman hem normlar hem bilgi verme yönüyle ortaya çıkmaktadır. Kimi zaman ise normatif ve bilgilendirici akran etkisinden birisi genç tüketicilerin eğilimleri üzerinde daha baskın olmaktadır. Arkadaş grubuyla olan samimiyetin düzeyi ya da genç tüketicinin grup aidiyeti de yenilikçilik eğilimleri üzerinde olumlu etkide bulunabilmektedir (Wang vd., 2012). Yerli yazında akran sosyalleşmesi tüketici yenilikçiliği ilişkisinin incelendiği bir araştırmaya rastlanmamıştır. Yerli yazında 
Töge'nin (2015) ulaştığı sonuçlar grup aidiyetinin, tüketim konusunda akranların birbirleriyle daha çok etkileşim kurmasını olumlu yönde etkilediğini göstermektedir. Tüm bu sonuçlar incelediğinde farklı yönleriyle akran etkileşiminin genç tüketicilerin yenilikçilik eğilimlerine nasıl yansıdığının tespit edilmesinin özellikle yerli yazın açısından katk1 sağlayacağı düşünülmektedir.

\section{KURAMSAL ÇERÇEVE}

Tüketici sosyalleşmesi yaklaşımı ilk olarak Ward (1974) tarafindan tüketici davranışlarını incelemek için bir araç olarak kullanılmıştır (Hayta, 2008: 167). Ward tüketici sosyalleşmesini, "gençlerin tüketici olarak etkin bir şekilde hareket etmeleri için gerekli olan beceri, bilgi ve tutumları elde ettikleri" bir süreç olarak tanımlamaktadır (Ward, 1974:2). Tüketici olarak bireylerin sosyalleşmelerinde etkili olan başlıca araçları aile, arkadaşlar, okul ve kitle iletişim araçları oluşturmaktadır (Moschis ve Churchill, 1978: 601). Çoğu tüketici davranış1 çocuklukta öğrenildiği için aile tüketici sosyalleşmesi açısından önemli bir araçtır. Bir çocuk ilk tüketim deneyimlerinde ürünlerin kullanımı ile ilgili bilgi edinirken, saygı duyduğu bir kaynak olarak ailesine başvurmaktadır (Kollat vd.,1970; Feltham, 1998: 372). Bu bilgi edinme ve tutum kazanma sürecinde, aile sahip olduğu değerler ve tüketim davranışlarını iletişim kurarak, çocuğun davranışlarını gözlemleyerek ve kendisinin gözlemlenmesini sağlayarak kolaylaştırır (Bearden ve Etzel, 1982: 184).

Çocuğun yaşı büyüdükçe özellikle ergenlik çağlarıyla birlikte anne-baba ve çocuk arasındaki kişisel ilişkilerin dönüşümü ile ebeveynlerin etkisi azalabilmektedir. İnformal akran grupları genç tüketicilerin tercih ettiği markalar üzerinde etkili olabilmektedir. Akran sözcügü, birbirlerini tanıyan, birbirleri ile zaman geçiren, bir şeyler paylaşan ve birbirlerinden etkilenen grup üyelerini ifade etmektedir (Niu, 2013: 1229). Akran gruplarının üyeleri, nispeten aynı yaşlardaki ve aynı öğrenme aşamasındaki bireylerden oluşmaktadır (Hemar-Nicolas vd., 2015: 318). Akran grubu içerisindeki üyeler aynı sosyo-ekonomik statü içerisinde yer alan, bilişsel yetenekler açısından benzer özelliklere sahip olan ve benzer yaşam çevrelerinden gelen bireylerden oluşmaktadır (Thaichon, 2013: 39). Bireyler akranlarının tutumlarını, fikirlerini aileden gelecek öğüt ve fikirlerden daha çok dinlemekte ve benimsemektedirler. Grubun önerdiği kısıtlamalar, özgürlük ve standartlar genç bireyler tarafından daha çabuk kabul edilmektedir (Yavuz, 1986: 86).

Akran grubu; ürünlerden ve markalardan haberdar olmayı, ürün hakkındaki inanç ve bilgileri, ürünün denenmesini, ürünün nasıl kullanılacağını, hangi ihtiyaçların tüketilen ürün ile karşılanacağını etkilemektedir (Odabaşı ve Barış, 2015: 229). Marka bilincinin geliştirilmesinde akran grubu önemli bir etkiye sahiptir. Akran grubu, belirli ürünler ve markalar hakkında bireyler için önemli bir bilgi kaynağıdır. Bireyler sıklıkla arkadaşlarıyla markalar ve reklamlar hakkında konuşmaktadır. Tüketim konularındaki bu etkileşim sonucunda, gençler akranlarının marka beğenilerini öğrenmekte ve markaları değerlendirirken veya satın alırken bunları göz önünde bulundurmaktadırlar (Valkenburg ve Buijen, 2005: 460). 
Deutsch ve Gerard (1955), kişilerarası etkileşimin normatif ve bilgilendirici olmak üzere iki kısımdan oluştuğu görüşündedirler. Burnkrant ve Cousineau (1975), normatif etkiyi başkalarının beklentilerine uyma eğilimi şeklinde tanımlamaktadırlar (aktaran: Bearden vd., 1989: 474). Normatif etki, sosyal bir gruba ait olmayı seçen bireylerin grup normlarına uymaya, tutumlarını ve davranışlarını akranların beklentilerine dayandırarak değiştirmeye iten etkidir. Bilgilendirici etki, satın alma kararı verirken ait olduğumuz grup üyelerinden satın alacağımız ürün veya hizmet ile ilgili bilgi sağlamadır. Normatif etki birey üzerinde doğrudan etki yaratmaktadır. Birey o gruba ait olabilmesi için hoşlanmasa dahi grup üyeleriyle benzer davranışlar göstermekte, grup normlarına uymaktadır. Bilgilendirici etki de ise dolaylı bir etki söz konusudur. Birey grup üyelerinden gözlemleyip öğrendiklerine güvenerek o doğrultuda satın alma kararını vermektedir (Wang vd., 2012: 201).

Akran sosyalleşmesi akranların arasındaki normatif ve bilgilendirici etkileşimin yanı sıra akranlar arasındaki bağ gücü (samimiyet düzeyi) ve grup aidiyeti açısından da ele alınmaktadır. Bağ gücü, bireyin akranlarıyla bir ilişkiyi sürdürmeyi isteme derecesini göstermektedir. Bu ilişki arkadaşlarımızla veya yakınlarımızla olduğu gibi güçlü olabilirken, tanıdık veya yabancı insanlarla olduğu gibi zayıf olabilmektedir (Wang vd., 2012: 201). Güçlü bağlar; ilişkinin özel ve samimi olduğu, ilişki için çaba harcandığı ve bunun sürdürülme arzusu, sık etkileşim içerisinde olma ve ilişkide karşılıklı paylaşım duygusunun gerekliliği olarak nitelendirilebilir (Brown vd., 2007: 4). Bağ gücü yüksek olan bireyler, zayıf bağ gücüne sahip kişilere göre daha sık etkileşime girerek daha fazla bilgi alışverişinde bulunurlar. Güçlü bağlar bireylerin davranışında zayıf bağlara göre daha fazla etki sahibidir (Brown ve Reingen, 1987: 353).

Birey ile akranlar arasındaki bağ, grup aidiyetliğinden önce gelir ve grup aidiyetliğine katkı sağlamaktadır. $\mathrm{Bu}$ nedenle akranlarla uyumlu bir ilişki, bireyleri diğer benzer grup üyeleriyle görüşüp etkileşimde bulunmaya yönlendirmektedir (Algesheimer vd., 2015: 23).

Akranlar genç tüketicilerin yeni ürünlerden haberdar olması ve grup normlarına uymak adına yeni ürünleri denemesi bakımından önemli bir referans aktörüdür. Yenilikçilik tüketici açısından ele alındığında, daha önceki seçimlere bağlı kalmak yerine, yeni ve farklı ürün / markalar satın almaya yatkınlık olarak açıklanmaktadır (Steenkamp vd., 1999: 56). İlgili yazında tüketici yenilikçiliği farklı bakış açılarıyla ele alınmaktadır. En çok yararlanılan bakış açılarından ilki tüketici yenilikçiliğini bir kişilik özelliği olarak ele almaktadır. Buna göre kişisel yenilikçilik (global / innate innovativeness), kişinin yeni fikirlere açık olması ve başkalarının tecrübelerinden bağımsız olma derecesidir. Kişisel yenilikçilik boyutu, yenilikçiliğin doğuştan geldiği ve kişisel özelliklere bağlı olduğu görüşüne dayanmaktadır (Midgley ve Dowling, 1978: 236). Kişisel yenilikçilik, bilişsel ve duyusal yenilikçilik olmak üzere iki alt boyuta ayrılır (Wood ve Swait, 2002: 2). Bilişsel yenilikçilik kavramayı, düşünmeyi teşvik eden yeni deneyimlerle uğraşma ve bunlardan zevk alma eğilimi olarak 
kavramsallaştırılmıştır (Pearson, 1970:200). Bilişsel yenilikçiler, düşünmekten, kafa yormaktan, sorun çözmekten zihinsel zorlamalardan zevk almakta ve bu zihinsel faaliyetleri teşvik eden yeni deneyimler aramaktadırlar (Venkatraman ve Price, 1990: 295). Zukerman (1979) duyusal yenilikçileri ise, fantezi ve hayal kurma gibi içsel olarak üretilen deneyimlerden ve paraşütle atlama gibi dışsal olarak heyecan verici maceraperest aktivitelerden etkilenme eğilimi olan kişiler olarak belirtmektedir (aktaran: Venkatraman ve Price, 1990: 295). Duyusal yenilikçiler keyiflenmek veya keyiflerini yerinde tutmak için yeni deneyimler yaşama eğilimindedirler (Venkatraman ve Price, 1990: 295).

Tüketici yenilikçiliği ile ilgili ikinci bakış açısı alana özgü/ürün yenilikçiliğidir. Ürün yenilikçiliği (domain specific/product category specific innovativeness) belirli bir ilgi alanı içindeki yenilikleri (yeni ürünleri) öğrenme eğilimi olarak tanımlanmıştır (Goldsmith ve Hofacker, 1991: 211). Bu bakış açısına göre yenilikçilik alana özgüdür yani tüketiciler belirli ürün kategorileri için yenilikçi olma eğilimindedir. Yenilikçiler kanaat önderi olabildikleri gibi, aynı zamanda o ürünün daha fazla kullanıcısı olduklarından yeni ürün hakkında daha bilgili oldukları düşünülmektedir (Goldsmith ve Newell, 1997: 163). Literatüre bakıldığında ürün temelli yenilikçiliğin moda ve teknoloji alanında yaygın olarak ele alındığı görülmektedir (Deniz, 2012: 68). Teknoloji; bilimsel yöntemleri kullanarak gerçek hayatta karşılaşılan problemlerin çözülmesinde bir köprü oluşturmaktır. Yenilik ise yeni bir şeyler yaratarak gelişmektir. Böylece yenilik, yeni teknoloji ve pazar firsatları oluşturarak üstünlük sağlamaktadır (Deniz, 2012: 70). Moda yenilikçileri, piyasaya yeni bir stil sunulduğunda bunun ilk alıcıları olarak tanımlanmıştır. Moda yenilikçilerinin yeni ürünlere olan tepkileri ürünün başarı veya başarısızlığını önemli ölçüde etkiler (Goldsmith vd.,1999: 7). Moda yenilikçileri giyim piyasasına yön veren kişilerdir. Moda yenilikçilerini belirlemek ve anlamak, üreticilerin yeni giyim stillerini daha etkili bir şekilde pazarlamasına yardımcı olmaktadır. Onların benimsedikleri stillere bakan diğer tüketiciler de bu stillerden etkilenmekte ve yenilikler bu yolla yaygınlaşmaktadır (Goldsmith vd., 1996: 242). Bu araştırmada tüketici yenilikçiliği ürün yenilikçiliği bakış açısıyla ele alınmaktadır. Araştırmada genç tüketicilere tüketim eğilimlerine uygun olması açısından ürün grubu olarak spor ayakkabı tercih edilmiş̧ir. Bu doğrultuda yenilikçilik ürün yenilikçiliğinin boyutu olan moda yenilikçiliği baz alınarak incelenmiştir.

\section{LITERATÜR TARAMASI}

İlgili yazın incelendiğinde akran sosyalleşmesi ve tüketici yenilikçiliğinin özellikle yabancı yazında farklı araştırmalarla ele alındığ 1 görülmektedir. Araştırmaların bir bölümünde akran sosyalleşmesi yenilikçilik ilişkisinin normatif ve bilgilendirici akran etkileşimi temelinde ele alındığı göze çarpmaktadır. Örneğin, Lachance vd.'ne (2003) göre ergenlik dönemindeki gençler açısından akranlar en önemli sosyalleşme aktörüdür ve arkadaşların en çok etkide bulundukları ürün grubu giyim ürünleridir. Çünkü bu dönemdeki gençler kıyafet, ayakkabı gibi giyim tercihleri yoluyla arkadaşlarıyla iletişim kurmaktadırlar. Gençlerin giyim tercihleri akran grubuna kabulün ön koşulu olabilmekte, grup 
üyelerinin onayları gençlerin satın alma kararlarını etkileyebilmektedir. Workman ve Studak'a (2006) göre genç tüketiciler modayı ve görünüşü gerek bireysel kimliklerini gerekse grup kimliklerini sergilemek için kullanmaktadır. Akran grubunun moda konusunda sahip olduğu normlar gençlerin satın alma tutumlarını ve davranışları etkilemektedir. Benzer biçimde Grewal vd. (2000) sosyal kimliği gözler önüne sermenin genç tüketicilerin sosyal bir ortama kabulünü kolaylaştırdığını, bu doğrultuda gençlerin yenilikçilik eğilimlerini etkilediğini ileri sürmektedir. Grewal ve arkadaşlarının ulaştıkları sonuçlara göre sosyal kimlik değişkeni gençlerin araba ve bilgisayar ürünlerinde yenilikçilik eğilimlerini önemli ölçüde etkilemektedir. Lee (2014) ise genç tüketicilerin bir yenilik olarak akıllı telefonları diğer tüketicilere göre daha erken benimsemesi üzerinde normatif akran etkileşiminin güçlü bir etkisinin olduğunu ileri sürmektedir. Çevresinde akıllı telefon kullanan arkadaşı çok olan genç tüketiciler yeni akıllı telefon modellerini daha erken benimsemektedir.

Bilgilendirici akran etkileşiminin yenilikçilik ile ilişkisi incelendiğinde Mangleburg ve Bristol (1998) genç tüketicilerin özellikle belirsizliğin yüksek olduğu tüketim deneyimlerinde, arkadaşlarının bilgisine başvurduklarını, ürünler hakkında bilgi düzeyi yüksek arkadaşlarından etkilendiklerini, bununla bağlantılı olarak pazar bilgilerinin arttığını öne sürmektedir. Araştırma sonuçlarına göre, genç tüketicilerin arkadaşlarıyla ürünler hakkında bilgi almak için sosyalleşmeleri, pazar bilgisi edinme düzeylerini pozitif etkilemektedir.

Normatif ve bilgilendirici akran etkileşiminin karşılaştırıldığı araştırmalarda ise farklı sonuçlara ulaşıldığı görülmektedir. Örneğin, Khare vd. (2012) Hindistan'da 18 ila 24 yaş arasındaki genç kadın tüketiciler kendilerinden büyük kadın tüketicilerle karşılaştırıldığında satın alma kararlarında bilgilendirici ve normatif etkileşimden daha çok yararlanmaktadır. Singh vd. (2003) ise farklı etnik gruplardaki genç tüketiciler üzerinde yaptıkları araştırmada bilgilendirici akran etkisinin ve internetin, pazar bilgisi edinmede normatif etkilere göre daha etkili olduğu sonucuna ulaşmıştır. Benzer şekilde Xie ve Singh (2007) üniversite öğrencileri açısından normatif akran sosyalleşmesinin yenilikçilik üzerinde negatif, bilgilendirici akran sosyalleşmesinin ise pozitif bir etkisinin olduğuna işaret etmektedir. Araştırmacılara göre bilgilendirici akran sosyalleşmesinin etkisi, normatif akran sosyalleşmesine göre daha güçlüdür. Buna karşılık Muratore (2008) genç tüketicilerin sanal bir platform olan blogları akranları ile ürün ve hizmetler hakkında bilgi almaya yönelik iletişim platformu olarak çok fazla kullanmadıklarına, bloglar üzerinden daha çok normatif bir etkileşimin var olduğuna işaret etmektedir.

$\mathrm{Az}$ sayıda araştırmada ise akran sosyalleşmesi genç tüketicilerin akranlarıyla bağ gücü (samimiyet düzeyi) ve grup aidiyeti açısından ele alınmıştır. Örneğin Wang vd.'ne (2012) göre sosyal medyadaki akran etkileşimini akranlarla olan bağın gücü pozitif yönde etkilemektedir. Bunun yanı sıra genç tüketicinin akran grubuna olan aidiyetinin yüksek olması da akran etkileşimini pozitif yönde etkilemektedir. Töge'nin (2015) ulaştığı sonuçlar ise Wang ve arkadaşlarının 
sonuçlarının aksine ergenlik çağındaki genç tüketicilerin akran grubuna aidiyetlerinin tüketim konularındaki akran etkileşimini pozitif etkilediğini, akranlarla olan bağ gücünün akran etkileşimi üzerinde etkisinin bulunmadığını göstermektedir.

Bazı araştırmalarda ise akranların genç tüketicilerin satın alma karar tarzlarını nasıl etkilediği sorusuna cevap aranmıştır. $\mathrm{Bu}$ araştırmalarda genel olarak akran etkileşimlerinin satın alma karar tarzlarından biri olan moda ve yenilikçi olma üzerinde pozitif bir etkiye sahip olduğu sonucuna ulaşılmıştır (Shim, 1996; Kamaruddin ve Mokhlis, 2003; Gentina vd., 2014). Kamaruddin ve Mokhlis (2003) akranların Malezyalı genç tüketicilerin satın alma karar sürecinde yenilikçi ve moda odaklı karar vermesini pozitif yönde etkilediğini ileri sürmektedir. Gentina vd. (2014) ise Fransız gençler Amerikalı gençlerle karşılaştırıldığında arkadaş onayının gençlerin moda ve yenilikçi karar vermeleri üzerinde daha fazla düzeyde pozitif yönde etkili olduğu sonucuna varmıştır.

\section{ARAŞTIRMANIN YÖNTEMI}

Araştırmanın amacı akran sosyalleşmesinin genç tüketicilerin moda yenilikçilik eğilimlerinde nasıl bir rol oynadığını belirlemektir. Çalışmada genç tüketicilerin akran sosyalleşmesi ve moda yenilikçilik eğilimlerini bakımından profillerini incelemek için betimsel araştırma modeli kullanılmıştır. Araştırmada katılımcıların akran sosyalleşmesine yönelik eğilimlerini daha ayrıntılı biçimde ortaya koyabilmek için, akran sosyalleşmesi hem normatif ve bilgilendirici olması açısından hem de grup üyelerinin arasındaki bağ gücü ve grup aidiyeti açısından ele alınmıştır. Araştırmanın genel amacı doğrultusunda şu sorulara yanıt aranmıştır:

1. Akran sosyalleşmesi ve moda yenilikçiliği yapıları hangi alt boyutlardan oluşmaktadir?

2. Genç tüketiciler akranlarıyla sosyalleşme eğilimlerine göre nasıl bir profile sahiptir?

3. Farklı profillerde yer alan genç tüketicilerin moda yenilikçilik eğilimleri farklılaşmakta mıdır?

Araştırmanın evreni, bir devlet üniversitesindeki İşletme Bölümü öğrencilerinden oluşmaktadır. Üniversite öğrencileri genç bireyleri temsil etme özelliklerinden dolayı, genç tüketicilerin satın alma davranışları üzerine yapılan araştırmalarda araştırma birimi olarak kullanılmaktadır (Xie ve Singh, 2007: 236). İlgili bölümde normal ve ikinci öğretime kayıtlı öğrenci sayısı 630'dur. Bu sayının 30'u normal ve ikinci öğretime devam eden birinci sınıf öğrencileridir. Geriye kalan 600 öğrenci ikinci, üçüncü ve dördüncü sınıflara devam eden öğrencilerden oluşmaktadır. Araştırmada zaman ve ulaşılabilirlik kısıtları göz önünde bulundurularak verilerin toplanmasında kolayda örnekleme tekniğinden yararlanılmıştır. Daha fazla katılımcıya ulaşmak için anket formları, her bir sınıfta zorunlu dersler esnasında dağıtılmıştır. Anket formu dağıtılmadan önce, katılımcılara araştırmanın konusundan ve anket formundan bahsedilmiştir. Böylelikle dersi alttan alıp anketi dolduran öğrencilerin tekrar anketi doldurmalarının önüne geçilmiştir. Derslere devam oranının ortalama \% 50 
civarında olması, ulaşılan öğrenci sayısını kısıtlamıştır. Saha çalışması 15 Nisan 2017 ile 25 Nisan 2017 tarihleri arasında tamamlanmıştır. Toplanan formlardan eksik ve hatalı doldurulan 5 form elenmiş ve analiz 245 veri toplama arac1 üzerinden gerçekleştirilmiştir.

Tablo 1. Katılımcıların Demografik Özellikleri

\begin{tabular}{|c|c|c|c|}
\hline \multicolumn{2}{|c|}{ Demografik Özellik } & $\mathbf{n}$ & $\%$ \\
\hline Cinsiyet & $\begin{array}{l}\text { Kadın } \\
\text { Erkek } \\
\text { Toplam }\end{array}$ & $\begin{array}{l}147 \\
98 \\
\mathbf{2 4 5}\end{array}$ & $\begin{array}{l}60 \\
40 \\
\mathbf{1 0 0}\end{array}$ \\
\hline Sinıf & $\begin{array}{l}1 \\
2 \\
3 \\
4 \\
\text { Toplam }\end{array}$ & $\begin{array}{l}27 \\
47 \\
93 \\
78 \\
\mathbf{2 4 5}\end{array}$ & $\begin{array}{l}11 \\
19,2 \\
38 \\
31,8 \\
\mathbf{1 0 0}\end{array}$ \\
\hline Gelir & $\begin{array}{l}1500 \text { ve altı } \\
1501-3000 \\
3001-4500 \\
4501-6000 \\
6001 \text { ve üstü } \\
\text { Toplam }\end{array}$ & $\begin{array}{l}63 \\
109 \\
51 \\
11 \\
11 \\
\mathbf{2 4 5}\end{array}$ & $\begin{array}{l}25,7 \\
44,5 \\
20,8 \\
4,5 \\
4,5 \\
\mathbf{1 0 0}\end{array}$ \\
\hline Öğrenim Türü & $\begin{array}{l}\text { Normal Öğrenim } \\
\text { İkinci Öğrenim } \\
\text { Toplam }\end{array}$ & $\begin{array}{l}128 \\
117 \\
\mathbf{2 4 5} \\
\end{array}$ & $\begin{array}{l}52,2 \\
47,8 \\
\mathbf{1 0 0} \\
\end{array}$ \\
\hline
\end{tabular}

Katılımcıların demografik özellikleri incelendiğinde cinsiyet bakımından kadınların erkeklerin önünde olduğu görülmektedir. Katılımcılar arasında 3. ve 4. sınıfta öğrenim görenlerin ağırlığı fazladır. Öğrenim türü açısından yarıya yarıya yakın bir dağılım söz konusudur. Katılımcıların aileleri arasında 1501-3000 TL arası gelire sahip aileler ilk sirada yer almaktadır.

Araştırmada tüketicilerin yenilikçilik eğilimlerinin ölçümünde ürün temelli yenilikçilik bakış açısından yararlanılmıştır. Yapılan araştırmalarda yenilikçiliğin ürün temelli ölçümü, teknoloji ve moda yenilikçiliği bağlamında bir ürün grubu özelinde ele alınmaktadır (Goldsmith ve Flynn, 1992; Workman ve Studak, 2006; Khare vd., 2012; Erciş ve Türk, 2012). Araştırmalarda moda yenilikçiliği bağlamında kıyafet, aksesuar, ayakkabı gibi ürünler seçilirken, teknoloji yenilikçiliği bağlamında ileri teknoloji ürünlerinin incelendiği görülmektedir. Bu araştırmada örneklem grubundaki erkek tüketicilerin kıyafet ve aksesuar ürünlerine yönelik ilgilenim düzeylerinin kadın tüketiciler kadar yoğun olmadığı gözlemlenmiş ve bu doğrultuda hem erkekler hem de kadınların tercih edebileceği bir ürün olarak spor ayakkabının uygun olacağı düşünülmüştür. Araştırmada iki bölümden oluşan bir veri toplama aracı geliştirilmiştir. Veri toplama aracının birinci bölümünde moda yenilikçiliği ve akran sosyalleşmesi ile ilgili ifadelere yer verilmiştir. Moda yenilikçiliği ile ilgili ifadelerin geliştirilmesinde Goldsmith ve Reinecke'in (1992) çalışmalarından yararlanılmıştır. Akran sosyalleşmesinin akranlarla bağ gücü ile akran grubuna aidiyet alt boyutlarına yönelik ifadeler Wang ve arkadaşlarının (2012) çalışmalarından yararlanılarak geliştirilmiştir. Akran sosyalleşmesinin diğer alt boyutları olan normatif ve bilgilendirici akran etkileşimi ile ilgili ifadelerin geliştirilmesinde ise, Xie ve Singh'in (2007) çalışmalarından faydalanılmıştır. 
Moda yenilikçiliği ve akran sosyalleşmesi ile ilgili ifadeler araştırmacılar tarafından Türkçe'ye çevrilmiştir. Ardından bir pazarlama alan uzmanı ile bir dil uzmanı ifadeleri anlaşılırlık ve dil kurallarına uygunluk açısından değerlendirmişlerdir. Pazarlama alan uzmanı ile araştırmacılar olası ürün seçeneklerini değerlendirmişler ve ürün grubu olarak spor ayakkabı konusunda nihai karara varmışlardır. Uzmanlardan gelen diğer dönütler doğrultusunda ifadeler üzerinde küçük biçimsel düzeltmeler yapılmıştır. Veri toplama aracının ikinci bölümde katılımcıların demografik özelliklerini ve spor ayakkabı satın alma davranışlarını belirlemeye yönelik 8 kapalı uçlu soruya yer verilmiştir.

Araştırmada moda yenilikçiliği ve akran sosyalleşmesi değişkenlerinin yapı geçerliliği açıklayıcı faktör analizi yoluyla test edilmiştir. Veri toplama aracında yer alan yapıların güvenirliğini belirlemek için Cronbach'ın $\alpha$ korelasyon katsayısı hesaplanmıştır.

\section{ARAŞTIRMANIN BULGULARI}

\section{Faktör Analizi Sonuçları}

\section{A. Akran Sosyalleşmesine ve Moda Yenilikçiliğine İlişkin Açıklayıcı}

Akran sosyalleşmesinin hangi alt boyutlardan oluştuğunu belirlemek amacıyla yapılan açıklayıcı faktör analizi sonucunda KMO değerinin 0,859, Barlett küresellik testi ve Ki-Kare değerlerinin anlamlı çıktığı görülmektedir. Akran sosyalleşmesine yönelik 16 ifade Tablo 2'de görüldügüü üzere üç faktör altında toplanmıştır. Bu faktörler toplam varyansın \% 63,840’1nı açıklamaktadır. Birinci faktör "Bă̆ Gücü (Samimiyet Düzeyi)", ikinci faktör "Akran Etkileşimi”, üçüncü faktör ise "Grup Aidiyeti” olarak isimlendirilmiştir. Faktörler güvenilirlik açısından incelendiğinde yüksek düzeyde güvenilir olduğu görülmektedir.

Tablo 2. Akran Sosyalleșmesi Açıklayıcı Faktör Analizi Sonuçları

\begin{tabular}{|l|c|c|c|}
\hline Maddeler & $\mathbf{1}$ & $\mathbf{2}$ & $\mathbf{3}$ \\
\hline Bağ Gücü (Samimiyet Düzeyi) & & & \\
\hline Akranlar için büyük iyilikler yapma & 0,850 & & \\
\hline Akranların büyük iyilikler yapması & 0,820 & & \\
\hline Akranlarla birlikte vakit geçirme & 0,797 & & \\
\hline Grubun önemli parçası olma & 0,726 & & \\
\hline Akranlarla sırlarını paylaşma & 0,635 & & \\
\hline Akranların yaptığı plana dahil olma & 0,605 & & \\
\hline Akran etkileşimi & & & \\
\hline Akranlardan bilgi alma & & 0,811 & \\
\hline Akranlara ürün hakkında sorular sorma & & 0,774 & \\
\hline Akranlardan yardım alma & & 0,761 & \\
\hline Akranların beğeneceği ürünleri satın alma & & 0,689 & \\
\hline Akranların aldığı ürüne bakma & & 0,686 & \\
\hline Akranların beğenilerinin önemli olması & & 0,666 & \\
\hline Akranlar üzerinde iyi bir etki bırakma & & 0,653 & \\
\hline Grup aidiyeti & & & \\
\hline Ortak amaçlara sahip olma & & & 0,752 \\
\hline Gruba bağlı olma & & & 0,742 \\
\hline Benim için arkadaşlarım çok şey ifade eder & & & 0,639 \\
\hline Özdeğer & 6,191 & 2,808 & 1,216 \\
\hline Açıklanan Varyans (\%) & 24,928 & 23,824 & 15,088 \\
\hline Cronbach $\boldsymbol{\alpha}$ & 0,883 & 0,861 & 0,818 \\
\hline
\end{tabular}

KMO Testi: 0,881 Bartlett küresellik testi $\chi^{2}: 2048,718 d f: 120$ p:0,00 
Moda yenilikçiliğinin tek boyutlu olup olmadığını test etmek için yapılan yapılan açıklayıcı faktör analizi sonucunda KMO değerinin 0,768 olarak hesaplandığ1, Barlett küresellik testi ve Ki- Kare değerlerinin ise anlamlı çıktığ görülmektedir. Moda yenilikçiliğine yönelik altı ifade orijinal ölçekteki gibi tek faktör altında toplanmıştır (Tablo 3). Faktör orijinal ölçekteki gibi "Moda Yenilikçiliği” olarak adlandırılmıştır. Bu tek faktör toplam varyansın \% 42,658'ini açıklamaktadır. Güvenilirlik açısından değerlendirildiğinde faktörün güvenirlilik katsayısının kabul edilen sınırın üstünde yer aldığı görülmektedir.

Tablo 3. Moda Yenilikçiliği Açıklayıcı Faktör Analizi Sonuçları

\begin{tabular}{|l|c|}
\hline Maddeler & $\mathbf{1}$ \\
\hline Moda Yenilikçiliği & 0,716 \\
\hline Diğerlerine göre daha çok bilgi sahibi olma & 0,707 \\
\hline Ürünü ilk alan olma & 0,695 \\
\hline Spor ayakkabılar hakkında az bilgi sahibi olma & 0,685 \\
\hline Ürünü hemen satın alma & 0,645 \\
\hline Ürünü satın alma sıklığı & 0,423 \\
\hline Fazla bilgi sahibi olmasa da satın alma & 2,559 \\
\hline Özdeğer & 42,658 \\
\hline Açılanan Varyans (\%) & 0,724 \\
\hline Cronbach $\boldsymbol{\alpha}$ & \\
\hline
\end{tabular}

KMO Testi: 0,768 Bartlett küresellik testi $\quad \chi 2: 267,271$ df: 15 p:0,00

\section{Eğilimleri}

\section{B. Katılımcıların Akran Sosyalleşmesi ve Moda Yenilikçiliğ}

Katılımcıların akran sosyalleşmesi ve moda yenilikçilik eğilimlerini belirlemek için ortalama, standart sapma ve tek örneklem t-testi değerleri Tablo 4'te verilmiştir. Tablo 4'de akran sosyalleşmesi ile ilgili bulgular incelendiğinde katılımcıların akranlarıyla kurdukları samimiyet düzeyi yüksek olduğu görülmektedir. Katılımcılar dahil oldukları akran grubuna kendilerini yüksek düzeyde bağlı hissetmektedirler. Buna karşılık yeni ürünlerle ilgili akranlardan bilgi edinme ve/veya akranlarının ürün tercihlerinin etkisinde kalma eğilimleri orta düzeyin altındadır. Katılımcıların spor ayakkabı bağlamında yenilikçilik eğilimlerinin de orta düzeyin altında olduğu görülmektedir.

Tablo 4. Katılımcıların Akran Sosyalleşmesi ve Moda Yenilikçiliği Eğilimleri

\begin{tabular}{|l|c|c|c|c|c|}
\hline Değişkenler & Ort. & SS & sd & t & p \\
\hline Bağ Gücü (Samimiyet Düzeyi) & 3,80 & 0,77 & 244 & 16,255 & $.000^{*}$ \\
\hline Akran etkileşimi & 2,80 & 0,80 & 244 & $-3,799$ & $.000^{*}$ \\
\hline Grup aidiyeti & 3,41 & 0,90 & 244 & 7,276 & $.000^{*}$ \\
\hline Moda yenilikçiliği & 2,74 & 0,64 & 244 & $-6,199$ & $.000^{*}$ \\
\hline${ }^{* p<.05}$
\end{tabular}

Öğrencilere spor ayakkabı tercihleri ile ilgili yöneltilen sorulara verdikleri cevaplara bakıldığında, yaklaşık olarak beşte birinin 2 veya daha fazla spor ayakkabıya sahip olduğu görülmektedir. Katılımcıların yarısından fazlası 6 ay -1 yıl gibi bir süre zarfında spor ayakkabı satın almakta, yarısına yakını spor ayakkabı için $101-200$ TL arasında bütçe ayırmaktadır. Spor ayakkabı tercihlerindeki ilk dört markayı Nike, Adidas, Puma ve Kinetix oluşturmaktadır. $\mathrm{Bu}$ markaları sirasiyla Hummel, New Balance, Converse, Reebok takip etmektedir. En az tercih edilen markalar içerisinde Lescon, Lacoste, Slazenger, 
Skechers ve Lotto gbi markalar yer almaktadır. Bu sonuçlar katılımcıların yenilikçilik eğilimleri ile birlikte değerlendirildiğinde, katılımcıların Nike, Adidas gibi diğer markalara göre daha pahalı markaları tercih ederken, bütçelerine göre hareket ettikleri ve ilgili markaların yeni modellerinden çok indirime giren eski modellerini tercih ettikleri söylenebilir.

Tablo 5. Katılımciların Spor Ayakkabı Tercihleri

\begin{tabular}{|l|l|l|l|}
\hline \multicolumn{2}{|c|}{} & n & \% \\
\hline Spor ayakkabı için ayrılan bütçe & 100 TL ve altı & 66 & 26,9 \\
& $101-200$ TL & 118 & 48,2 \\
& $201-300$ TL & 50 & 20,4 \\
& $301-400$ TL & 8 & 3,3 \\
& 401 TL ve üzeri & 3 & 1,2 \\
& Toplam & $\mathbf{2 4 5}$ & $\mathbf{1 0 0}$ \\
\hline Spor ayakkabı sayısı & Hiç yok & 3 & 1,2 \\
& 1 & 35 & 14,3 \\
& 2 & 75 & 30,6 \\
& 3 & 65 & 26,5 \\
& 4 ve üzeri & 67 & 27,3 \\
& Toplam & $\mathbf{2 4 5}$ & $\mathbf{1 0 0}$ \\
\hline Satın alma sıklığı & 6 aydan az & 38 & 15,5 \\
& 6 ay - 1 yıl & 131 & 53,5 \\
& 1 yil - 2 yıl & 60 & 24,1 \\
& 2 yll - 3 yil & 11 & 4,5 \\
& 3 yldan fazla & 5 & 2,0 \\
& Toplam & $\mathbf{2 4 5}$ & $\mathbf{1 0 0}$ \\
\hline
\end{tabular}

\section{Katılımeıların Akran Sosyalleşmesi ve Moda Yenilikçiliği}

\section{Profilleri}

Katılımcıları akran sosyalleşmesinin üç alt grubu itibariyle gruplara ayırmak amacıyla kümeleme analizinden yararlanılmıştır. Analiz kapsamında Ward tekniği ile hiyerarşik kümeleme analizi yapılmış ve ideal küme sayısı belirlenmeye çalışılmıştır. Bu analizde elde edilen dendogram çıktısı ideal küme sayısının üç olduğunu göstermiştir. Üçlü küme yapısının geçerliliğini test etmek ve kümeleri betimleyen özellikleri belirlemek için hiyerarşik olmayan kümeleme tekniklerinden K-means kümeleme kullanılmıştır. K-means kümeleme ve hiyerarşik kümeleme bulgularından elde edilen ortalamaların birbirlerine yakınlıkları incelenmiş ve ortalamaların yakın olduğu görülmüştür. K-means kümelemeden elde edilen küme ortalamaları ve her bir kümedeki gözlem sayıları Tablo 6' da yer almaktadir.

Tablo 6. Katılımcıların Akran Sosyalleşmesi Açısından Profilleri

\begin{tabular}{|l|c|c|c|}
\hline Akran Sosyalleşmesi & $\begin{array}{c}\text { 1. küme } \\
\text { (n=130) }\end{array}$ & $\begin{array}{c}\mathbf{2 . ~ k u ̈ m e} \\
(\mathbf{n = 5 9 )}\end{array}$ & $\begin{array}{c}\text { 3. küme } \\
(\mathbf{n = 5 6})\end{array}$ \\
\hline Akran etkileşimi & 2,79 & 3,43 & 2,19 \\
\hline Bağ gücü & 3,82 & 4,62 & 2,93 \\
\hline Grup aidiyeti & 3,38 & 4,53 & 2,33 \\
\hline
\end{tabular}

Tablo incelendiğinde katılımcıların yarıdan fazlasının kümede yer alan katılımcılar diğer kümelerin arasında bir profil sergiledikleri 1. kümede yer aldıkları görülmektedir. 1. kümedeki katılımcıların dahil oldukları akran grubundaki arkadaşlarıyla yüksek oranda samimidirler. Bu gruptaki katılımcıları arkadaşlarıyla birlikte vakit geçirmekte, kişisel sırlarını paylaşmakta, onlar için 
iyilik yapmakta ve onlar tarafindan iyilik görmektedirler. Bu kümedeki katılımcılar grup aidiyeti bakımından ise orta düzeyde bir profile sahiptir. Bir başka ifadeyle 1. kümedeki katılımcılar gruba olan bağlılıkları ve grup arkadaşlarıyla ortak amaçlara sahip olma eğilimleri bakımından 2. kümenin gerisinde, 3. kümenin önünde yer almaktadırlar. Bu kümedeki katılımcıların akran grubundaki arkadaşlarıyla ürünler hakkındaki etkileşimlerinin de orta düzey olduğu söylenebilir. Bir diğer deyişle 1. kümedeki katılımcılar arkadaşlarıyla spor ayakkabıları hakkında bilgi alma bakımından (bilgilendirici akran sosyalleşmesi) orta düzeyde sosyalleşmektedirler. Benzer şekilde bu kümedeki katılımcılar arkadaşlarının aldığı spor ayakkabıları inceleme, onların beğeneceği ayakkabıları tercih etme ve spor ayakkabılarıyla onlar üzerinde iyi bir etki bırakma istekleri (normatif akran sosyalleşmesi) orta düzeydedir. Bu bulgular 1şığında 1. küme "arada kalanlar" olarak adlandırılmıştır.

2. kümedeki katılımcıları toplam katılımcıların yaklaşık dörtte birini oluşturmaktadır. Bu kümedeki katılımcıları akran grubundaki arkadaşlarıyla çok yüksek düzeyde samimidirler. Aynı zamanda dahil oldukları akran grubuna çok yüksek düzeyde bağlıdırlar. 2. kümedeki katılımcılar diğer kümelerle karşılaştırıldığında arkadaşlarıyla normatif ve bilgilendirici anlamda yüksek oranda sosyalleşmektedirler. Bu kümedeki katılımcılar akran sosyalleşmesinin her üç alt boyutu açısından diğer kümelerin önünde yer almaktadırlar. Bu nedenle bu küme "arkadaş tutkunları" olarak adlandırılmıştır.

Katılımcıların yaklaşık olarak kalan dörtte birlik bölümü 3. küme içerisinde yer almaktadır. Bu kümedeki katılımcılar akran etkileşimi, grup aidiyeti ve bağ gücü bakımından diğer iki kümenin gerisinde bir profile sahiptirler. 3 . kümedeki katılımcılar arkadaşlarıyla orta düzeyde birlikte vakit geçirmekte, sırlarını paylaşmakta ve gerektiğinde onlar için iyilik yapmaktadırlar. Ancak birlikte vakti geçirmenin onların grup aidiyetlerine olumlu yönde yansımadığ söylenebilir. Bu kümedeki katılımcıların gruba olan bağlılıkları düşük düzeydedir. Ürünler hakkında gerek bilgilendirici gerekse normatif bağlamda akranlarıyla düşük düzeyde sosyalleşmektedirler. $\mathrm{Bu}$ bulgular doğrultusunda 3 . küme "bağımsızlar" olarak adlandırılmıştır.

Araştırmada her üç kümedeki katılımcıların moda yenilikçilik eğilimlerinin farklılaşıp farklılaşmadığını belirlemek için tek yönlü varyans analizinden yararlanılmıştır. Analiz sonucunda elde edilen bulgular kümeler arasında moda yenilikçiliği açısından anlamlı fark bulunduğunu göstermektedir. Kümeler arasında moda yenilikçilik eğilimleri bakımından da akran sosyalleşmesi ortalamalarına benzer bir görünüm söz konusudur. Arkadaş tutkunlarının spor ayakkab1 özelindeki yenilikçilik eğilimleri diğer kümelerin önünde yer almaktadır. Arada kalanlar spor ayakkabılar konusunda bilgi sahibi olma ve hemen satın alma eğilimleri açısından arkadaş tutkunlarının gerisinde, bağımsızların önünde yer almaktadır. Bireysel davrananlar ise, spor ayakkabı ürünü özelinde düşük düzeyde yenilikçidirler. 
Tablo 7. Kümelerin Moda Yenilikçiliği Eğilimleri

\begin{tabular}{|l|c|c|}
\hline Kümeler & Ort. & SS \\
\hline Arkadaş tutkunları & 2,89 & 0,71 \\
\hline Arada kalanlar & 2,75 & 0,58 \\
\hline Bağımsızlar & 2,54 & 0,68 \\
\hline
\end{tabular}

Farklılı̆̆ın hangi gruplardan kaynaklandığını belirlemek için yapılan posthoc testlerinde, arkadaş tutkunları ile bağımsızların moda yenilikçilik eğilimleri arasında anlamlı fark bulunmuştur.

Tablo 8. Kümelerin Moda Yenilikçiliği Eğilimlerine İlişkin Tek Yönlü Varyans Analizi Sonuçları

\begin{tabular}{|l|c|c|c|c|c|c|}
\hline Varyansın Kaynağı & $\begin{array}{c}\text { Kareler } \\
\text { Toplamı }\end{array}$ & sd & $\begin{array}{c}\text { Kareler } \\
\text { Ortalaması }\end{array}$ & F & p & Anlamlı Fark \\
\hline Gruplararası & 3,538 & 2 & 1,769 & 4,310 & $.014^{*}$ & $\begin{array}{c}\text { Arkadaş } \\
\text { tutkunları }- \\
\text { Bağımsılar }\end{array}$ \\
\hline Gruplariçi & 99,318 & 242 & 0,410 & & & \\
\hline Toplam & 102,856 & 244 & & & & \\
\hline
\end{tabular}

\section{SONUÇ}

$\mathrm{Bu}$ araştırmada akran sosyalleşmesinin genç tüketicilerin moda yenilikçilik eğilimlerinde nasıl bir rol oynadığını tespit etmek için üniversite öğrencilerinden kolayda örneklem yoluyla veri toplanmıştır. Genç tüketicilerin yenilikçilik eğilimleri bir ürün grubu özelinde belirlenmeye çalışılmıştır. Ürün grubu olarak gençlerin günlük yaşamlarında tercih ettikleri bir ayakkabı türü olan spor ayakkabı seçilmiştir. Araştırmada geçerlilik çalışmalarının ardından akran sosyalleşmesinin normatif ve bilgilendirici nitelikteki sosyalleşmeyi ifade eden akran etkileşimi, dahil olunan akran grubuyla samimi ilişkileri ifade eden bağ gücü ve grup aidiyeti olmak üzere üç alt boyutu kapsadığı ortaya çıkmıştır. Tüketici yenilikçiliği ise moda yenilikçiliği bağlamında değerlendirilmiştir.

Araştırma bulguları katılımcıların akranlarıyla aralarında yüksek düzeyde samimi ilişkilerin olduğu ve grup aidiyetlerinin olduğunu göstermektedir. Bununla birlikte akranlarla yaşanan etkileşimler içerisinde spor ayakkabı özelindeki etkileşimlerin ve yenilikçilik eğilimlerinin orta düzeyde olduğu görülmektedir. Katılımcıların akranlarıyla aralarında bağ gücü ve grup aidiyetleri yüksek iken, ürünler konusunda akran etkileşiminin orta düzeyde olmas1, katılımcıların satın alma kararlarında başkalarından etkilendiklerini çok kabul etmek istememelerinden, ideal cevabı verme eğilimlerinden kaynaklanabilir. Bu sonuç üzerinde ayrıca etkileşimin spesifik bir ürün özelinde ölçülmesi de etkili olabilir. Yenilikçilik eğilimlerinin orta düzeyde olmasının ise, katılımcıların ailelerinin genel olarak çok yüksek gelirlere sahip olmamasından kaynaklandığ düşünülmektedir. Katılımcıların yarısına yakını spor ayakkabı için 100 ila $200 \mathrm{TL}$ arasında bütçe ayırmakta ve ortalama yılda bir spor ayakkabı satın almaktadır. Her on katılımcıdan üçünün iki tane spor ayakkabısı bulunmaktadır. Tercih edilen markalar arasında ilk üç sırada Nike, Adidas ve Kinetix yer almaktadır. Genç tüketiciler genel olarak en çok tercih edilen spor ayakkabı markalarını tercih etmektedir. Spor ayakkabı için ortalama bir bütçe ayırdıkları ve genel yenilikçilik eğilimlerinin ortalamanın altında olduğu göz önünde bulundurulduğunda bu 
markaların bazılarını satın almak için eski modellerin indirim dönemlerini bekledikleri söylenebilir.

Katılımcılar akran sosyalleşmesi açısından düşük, orta ve yüksek eğilimlilerin yer aldığı üç farklı kümede toplanmıştır. $\mathrm{Bu}$ kümeler, arkadaş tutkunları, arada kalanlar ve bağımsızlar olarak adlandırılmıştır. Katılımcıların yarıdan fazlası arada kalanlar grubunda yer alırken, geriye kalan kısmı arkadaş tutkunları ve bağımsızlar kümelerine neredeyse eşit oranda dağılmıştır. Moda yenilikçiliği açısından incelendiğinde akran sosyalleşmesindeki küme ortalamalarına benzer bir eğilim tespit edilmiştir. Akranlarıyla aralarındaki bağ gücü ve grup aidiyetleri çok yüksek olan, spor ayakkabılar konusunda yüksek düzeyde akranlarıyla sohbet eden, onların ayakkabılarını inceleyen, kendi ayakkabı tercihleriyle akran grubunu etkilemek isteyen arkadaş tutkunları, kümeler içerisindeki en yenilikçi gruptur. Wang vd.'nin (2012) ulaştığı sonuçlarda akranlarıyla bağ gücü yüksek gençler de akran etkileşiminin daha fazla olduğu, samimi ilişkilerin etkileşimi pozitif etkilediği görülmektedir. Kamaruddin ve Mokhlis (2003) akran etkileşiminin yenilikçi karar vermeyi olumlu etkilediğini ileri sürmektedir. Lachance vd. (2003) ile Workman ve Studak (2006) ise akran grubu onayının, grup normlarının gençlerin satın alma tutumlarına yansıdığını ifade etmektedir. Bu bulgular arkadaş tutkunlarının eğilimleriyle örtüşmektedir.

Akranlarıyla çok vakit geçiren, sosyalleşmeye çok önem veren ancak kendini gruba çok ait hissetmeyen ve akranlarından ürünler hakkında çok fazla bilgi almayı tercih etmeyen gençlerin (arada kalanların) yenilikçilik eğilimleri arkadaş tutkunlarından çok farklı değildir. Bu sonuç birbirleriyle çok zaman geçirmenin, kişisel sırlarını paylaşmanın, yakın olmanın tutum ve eğilimlere yansıdığını göstermektedir. Arkadaşlarıyla mesafeli ilişkileri olan, bir gruba ait olmaktan çok hoşlanmayan gençlerin yenilikçilik özellikleri de düşüktür. Etkileşimin az olması gençlerin yeni ürünleri daha geç farketmelerine, bu ürünlerle hemen ilgilenmemelerine neden olabilir.

$\mathrm{Bu}$ araştırma biri devlet üniversitesindeki İşletme Bölümü öğrencileri üzerinde yapılmıştır. Gelecekte daha büyük örneklemler üzerinde yapılacak araştırmalar ile devlet üniversiteleri ile özel üniversitelere devam eden öğrenciler karşılaştırılabilir. Böylelikle daha yüksek gelire sahip genç tüketiciler ile orta ve düşük gelire sahip genç tüketicilerin yenilikçilik eğilimleri karşılaştırılabilir. Ayrıca farklı bölümlere devam eden öğrencilerin karşılaştırıldığı araştırmalar tasarlanabilir. $\mathrm{Bu}$ araştırmanın bir başka sınırlılığı tüketici yenilikçiliğinin bir ürün grubu ile belirlenmiş olmasıdır. Gelecekte moda yenilikçiliğinin akıllı telefon, kişisel bakım ürünleri, aksesuar gibi farklı ürün grupları açısından ele alındığı araştırmalarla yenilikçilik eğilimlerinin farklılaşıp farklılaşmadığı ortaya çıkarılabilir. Gelecekte yapılacak araştırmalarda tüketici yenilikçiliği ürün temelli bakış açısının yanında diğer bakış açıları (örneğin, güdülenmiş tüketici yenilikçiliği gibi) yoluyla değerlendirilerek yenilikçiliğe ilişkin daha ayrıntılı bulgulara ulaşılabilir. Gelecekte yapılacak araştırmalarda ayrıca akran sosyalleşmesi ve yenilikçilik bakımından farklı profiller sergileyen genç 
tüketicileri betimleyen farklı özelliklerin neler olduğunun ortaya çıkarılması için nitel araştırmalar desenlenebilir.

Akranlarıyla güçlü düzeyde samimi ilişkileri olan, ürünler hakkında sohbet eden, kullandığ 1 ürünlerle akran grubunu etkilemeye çalışan genç tüketicilerin yenilikçilik eğilimlerinin yüksek olduğu göz önünde bulundurulduğunda, gençlere yönelik yeni ürünlerin tutundurulmasında referans grubu olarak akranlara başvurmak bir seçenek olabilir. Akran temalı tutundurma mesajları genç tüketicilerin yeni ürünleri benimsemesinde etkili olabilir. Uygulamacılar iletişim stratejilerinde akranlarla olan samimi ilişkilerin, bilgilendirici ve normatif akran sohbetlerinin işlendiği mesajlar tasarlayabilirler. Sosyal medyayı ve interneti aktif olarak kullanan bu gruba ulaşmada genç ve takipçi sayısı fazla olan youtuberlar ve instagram fenomenleri kullanılabilir. $\mathrm{Bu}$ kişiler yeni ürünlerin tanıtımında birer etkileyici olarak kullanılarak ağızdan ağıza iletişim yoluyla genç tüketicilerin yeni ürünleri daha hızlı şekilde benimsemesi sağlanabilir. Etkileyiciler, yeni ürün tanıtımlarında ürünün sosyal, hedonik yararları hakkında eğlendirici mesajlar sunabilirler.

\section{KAYNAKÇA}

Algesheimer, R., Dholakia, U. M. and Herrmann, A. (2005). The Social Influence of Brand Community: Evidence from European Car Clubs. Journal of Marketing, 69(3), 19-34.

Bearden, W. O. and Etzel, M. J. (1982). Reference Group Influence on Product and Brand Purchase Decisions. Journal of Consumer Research, 9(2), 183-194.

Bearden, W. O., Netemeyer, R. G. and Teel, J. E. (1989). Measurement of Consumer Susceptibility to Interpersonal Influence. Journal of Consumer Research, 15(4), 473-481.

Brown, J. J. and Reingen, P. H. (1987). Social Ties and Word-Of-Mouth Referral Behavior. Journal of Consumer research, 14(3), 350-362.

Brown, J., Broderick, A. J. and Lee, N. (2007). Word Of Mouth Communication within Online Communities: Conceptualizing the Online Social Network. Journal of Interactive Marketing, 21(3), 2-20.

Deniz, A. (2012). Tüketici Yenilikçiliğinin Boyutları ve Yenilikçiliği Etkileyen Faktörler Arasındaki İlişkiler. Atatürk Üniversitesi Sosyal Bilimler Enstitüsü, Doktora Tezi.

Deutsch, M. and Gerard, H. B. (1955). A Study of Normative and Informational Social Influences upon Individual Judgment. The Journal of Abnormal and Social Psychology, 51(3), 629636.

Erciş, A. ve Türk, B. (2012). Tüketici Yenilikçiliğinin Moda Ürünleri Benimseme Eğilimi Üzerindeki Etkileri. 1. Isşletme Yönetimi ve Kurumsal Sosyal Sorumluluk Uluslararası Bilimsel Kongresi, 23-25 Kasım 2012 Bakü, 507-517.

Feltham, T. S. (1998). Leaving Home: Brand Purchase Influences On Young Adults. Journal of Consumer Marketing, 15(4), 372-385.

Gentina, E., Butori, R., Rose, G. M. and Baki, A. (2014). How National Culture Impacts Teenage Shopping Behavior: Comparings French and American Consumers. Journal of Business Research, 67(2014), 464-470.

Goldsmith, R. E. and Flynn, L. R. (1992). Identifying Innovators in Consumer Product Markets. European Journal of Marketing, 26(12), 42-55.

Goldsmith, R. E. and Hofacker, C. F. (1991). Measuring Consumer Innovativeness. Journal of the Academy of Marketing Science, 19(3), 209-221.

Goldsmith, R. E. and Newell, S. J. (1997). Innovativeness and Price Sensitivity: Managerial, Theoretical and Methodological Issues. Journal of Product \& Brand Management, 6(3), 163-174.

Goldsmith, R. E., Flynn, L. R. and Moore, M. A. (1996). The Self-Concept of Fashion Leaders. Clothing and Textiles Research Journal, 14(4), 242-248. 
Tuğba Kılıçer \& Eda Paç Çelik / 'Bana Arkadaşını Söyle, Sana Yenilikçi Olup Olmadı̆̆ını Söyleyeyim': Akran Sosyalleşmesinin Tüketici Yenilikçiliğindeki Rolü

Goldsmith, R. E., Moore, M. A. and Beaudoin, P. (1999). Fashion Innovativeness and Self-Concept: A Replication. Journal of Product \& Brand Management, 8(1), 7-18.

Goldsmith, R. E. and Flynn L.R. (1992). Identifying Innovators in Consumer Product Markets. European Journal of Marketing, 26(12), 42-55.

Grewal, R., Mehta, R. and Kardes, F. R. (2000). The Role of the Social-identity Function of Attitudes in Consumer Innovativeness and Opinion Leadership. Journal of Economic Psychology, 21 (2000) 233-252.

Hayta, A. B. (2008). Socialization of the Child as a Consumer. Family and Consumer Sciences Research Journal, 37(2), 167-184.

Hemar-Nicolas, V., Gollety, M., Damay, C. and Ezan, P. (2015). "What Brand Do You Eat?" The Influence of Food Brands within Children's Peer Groups. Young Consumers, 16(3), 316331.

Kamaruddin, A. R. and Mokhlis, S. (2003). Consumer Socialization, Social Structural Factors and Decision-Making Styles: A Case Study of Adolescents in Malaysia. International Journal of Consumer Studies, 27(2), 145-156.

Khare, A., Parveen, C. and Mishra A. (2012). Influence of Normative and Informative Values on Fashion Clothing Involvement of Indian Women. Journal of Customer Behaviour, 11(1), 9-32.

Lachance, M. J., Beaudoin, P. and Robitaille, J. (2006). Adolescents' Brand Sensitivity in Apparel: Influence of Three Socialization Agents. International Journal of Consumer Studies, 27(1), 47-57.

Lee, S. Y. (2014). Examining The Factors That Influence Early Adopters' Smartphone Adoption: The Case of College Students. Telematics and Informatics, 31(2014), 308-318.

Mangleburg, T. F. and Bristol, T. (1998). Socialization and Adolescents' Skepticism toward Advertising. Journal of Advertising, 27(3), 11-21.

Midgley, D. F. and Dowling, G. R. (1978). Innovativeness: The Concept and its Measurement. Journal of Consumer Research, 4(4), 229-242.

Moschis, G. P. and Churchill Jr, G. A. (1978). Consumer Socialization: A Theoretical and Empirical Analysis. Journal of Marketing Research, 599-609.

Muratore, I. (2008). Teenagers, Blogs and Socialization: A Case Study of Young French Bloggers. Young Consumers, 9(2), 131-142.

Niu, H. J. (2013). Cyber Peers' Influence for Adolescent Consumer in Decision-Making Styles and Online Purchasing Behavior. Journal of Applied Social Psychology, 43, 1228-1237.

Odabaşı, Y. ve Barış, G. (2015). Tüketici Davranışı. MediaCat Akademi.

Pearson, P. H. (1970). Relationships between Global and Specified Measures of Novelty Seeking. Journal of Consulting and Clinical Psychology, 34(2), 199-204.

Shim, So. (1996). Adolescent Consumer Decision-Making Styles: The Consumer Socialization Perspective. Psychology \& Marketing, 13(6), 547-569.

Singh, N., Kwon, I. W. and Pereira, A. (2003). Cross-Cultural Consumer Socialization: An Exploratory Study of Socialization Influences across Three Ethnic Groups. Psychology \& Marketing, 20(10), 867-881.

Steenkamp, J. B. E. M, Hofstede, F. T. and Wedel, M. (1999). A Cross-National Investigation into the Individual and National Cultural Antecedents of Consumer Innovativeness. The Journal of Marketing, 55-69.

Thaichon, Park (2017). Consumer Socialization Process: The Role of Age in Children's Online Shopping Behavior. Journal of Retailing and Consumer Services, 34(2017), 38-47.

Töge, B. (2015). Sosyal Ağlarda Tüketim Temelli Akran İletişiminin İncelenmesi: Adana İlinde Bir Uygulama. Çukurova Üniversitesi Sosyal Bilimler Enstitüsü, Yayınlanmamış Yüksek Lisans Tezi.

Valkenburg, P. M. and Buijzen, M. (2005). Identifying Determinants of Young Children's Brand Awareness: Television, Parents, and Peers. Journal of Applied Developmental Psychology, 26(4), 456-468. 
Venkatraman, M. P. and Price, L. L. (1990). Differentiating Between Cognitive and Sensory Innovativeness: Concepts, Measurement, and Implications. Journal of Business Research, 20(4), 293-315.

Wang, X., Yu, C. and Wei, Y. (2012). Social Media Peer Communication and Impacts on Purchase Intentions: A Consumer Socialization Framework. Journal of Interactive Marketing, 26 (2012) 198-208.

Ward, S. (1974). Consumer Socialization. Journal of Consumer Research, 1(2), 1-14.

Wood, S. L. and Swait, J. (2002). Psychological Indicators of Innovation Adoption: CrossClassification Based on Need for Cognition and Need For Change. Journal of Consumer Psychology, 12(1), 1-13.

Workman, J. E. and Studak, C. M. (2006). Fashion Consumers and Fashion Problem Recognition Style. International Journal of Consumer Studies, 30(1), 75-84.

Xie, Y. H. and Singh, N. (2007). The Impact of Young Adults' Socialisation on Consumer Innovativeness. Journal of Customer Behaviour, 6(3), 229-248.

Yavuz, H. (1986). Ergenlik Çağında Gelişmeyi Etkileyen Güçler. Boğaziçi Üniversitesi Yayınları. İstanbul.

\section{SUMMARY}

Peer groups are important parts of young consumers' daily lifes. Young consumers spend time, socialize, and consume products and services with their peer groups. Young consumers pay attention to which brands peers have and their interest towards new products during the socialization process. Besides peers advise about products and brands on this process. When young consumers take an important part in peer group, the effect of peers' recommendations increase on product chocies of young consumers. Thus normative and informative peer interaction is seen between group members. Tie strength and group identification are factors effect the interaction between peers. Tie strength is the degree to which a person is willing to maintain some relationship with peers. Group identification is defined as the features of a self-inclusive social category that renders self stereotypically interchangeable with other in-group members.

In this context, the aim of this study is to investigate the role of peer socialization on consumer innovativeness of young consumers. A questionnaire was applied to students attending Business Administration Department in a state university. It was utilized factor analysis, cluster analysis and one way ANOVA to analyze the data. Participants could be grouped in three separate clusters with respect to their adoption of peer socialization. The participants in each cluster display distinctive profiles in terms of peer socialization and consumer innovativeness. Clusters are named as 'friend devotees', 'piggies in the middle' and 'dependents'. Friend devotess have highest tendencies with respect to the group identification, tie strength and peer interaction. Fashion innovativeness tendency of friend devotees is highest in these distinctive profiles. Piggies in the middle have tendencies between 'friend devotees' and 'dependents' in terms of group identification, tie strength and peer interaction. Their tendencies in terms of fashion innovativeness are higher than 'dependents' and lower than 'friend devotees'. On the other hand, dependents have the lowest tendencies in terms of group identification, tie strength and peer interaction. Fashion innovativeness tendency of dependents is lower than the other clusters. This study will also discuss managerial implications and direction for future research. 